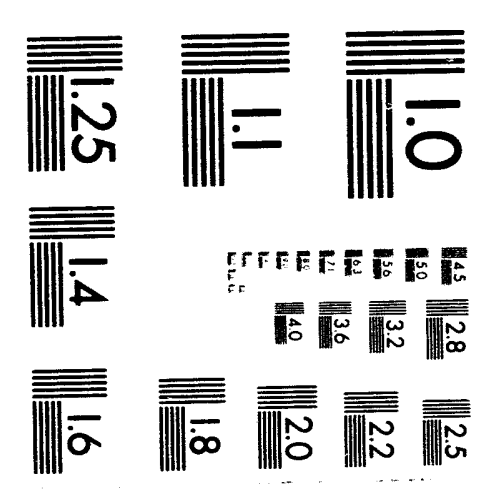



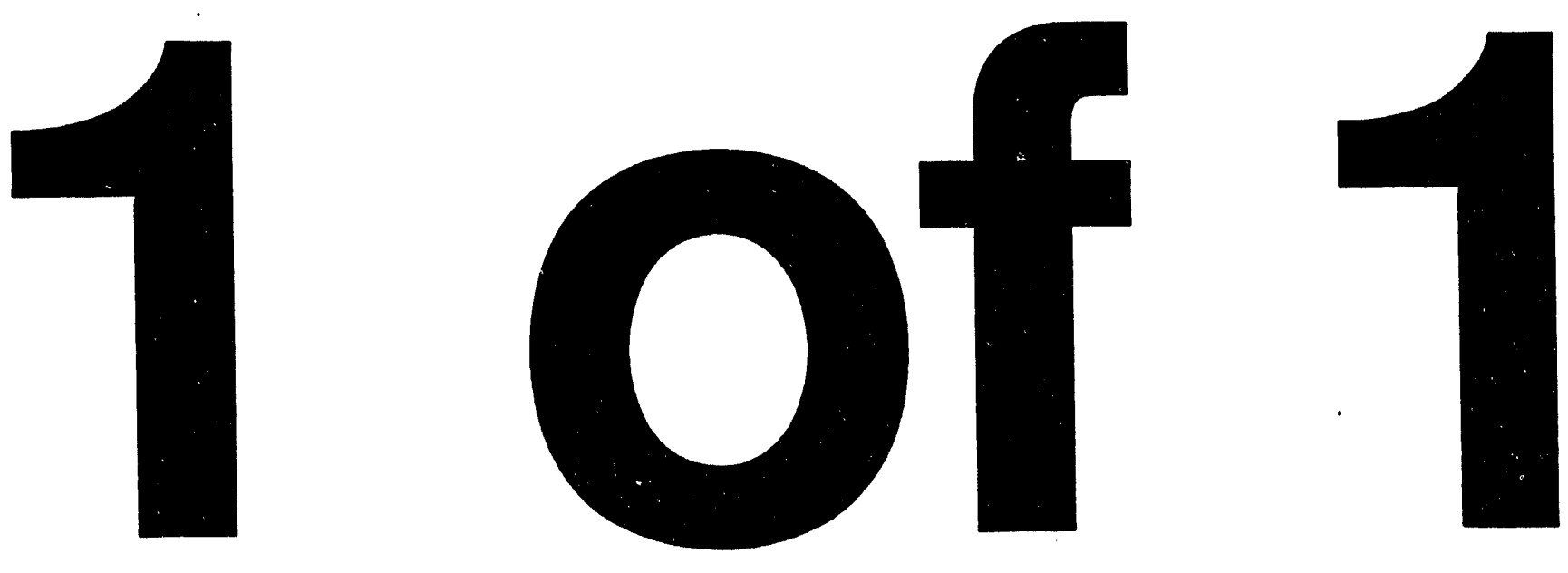


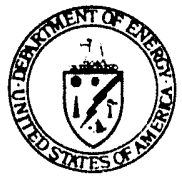

\title{
RCRA and CERCLA Requirements Associated with the Sale or Transfer of DOE Property
}

BACKGROUND:

\begin{abstract}
In an effort to mitigate adverse economic effects of the reconfiguration and reduction in size of the Defense complex, Congress passed the Community Environmental Response Facilitation Act (CERFA) in October 1992. This legislation amends the Comprehensive Environmental Response, Compensation, and Liability Act (CERCLA) to establish a process for Identifying, prior to the termination of Federal activities, property that does not contain contamination from the storage, release, or disposal of hazardous substances or petroleum products or their derivatives. The prompt Identification of property that will not require environmental remediation is intended to facilitate the transfer of such property for economic redevelopment purposes. Other Federal laws, such as the Resource Conservation and Recovery Act (RCRA), contain requirements pertinent to the sale or transfer of DOE property. This information Brief summarizes the RCRA and CERCLA statutory and regulatory requirements pertinent to the sale or transfer of DOE property.
\end{abstract}

STATUTE: RCRA Section 3004(a)(6) and CERCLA Section 120(h).

REGULATIONS:

40 CFR 264 "Standards for owners and operators of hazardous waste treatment, storage, and disposal facilities," Sections 264.116 and 264.119 (a) and (b).

40 CFR 265 "Interim status standards for owners and operators of hazardous waste treatment, storage, and disposal facilities," Sections 265.116 and 265.119 (a) and (b).

40 CFR 373 "Reporting hazardous substance activity when selling or transferring Feceral real property."

REFERENCE:

"Closure of Hazardous and Mixed Radioactive Waste Management Units at DOE Facillties," U.S. Department of Energy, Oftice of Environmental Guidance, RCRACERCLA Division, June 1990 (DOEJEGD-RCRA-002/0690).

Which RCRA regulations are pertınent to the sale or transfer of DOE property?

The RCRA regulations pertinent to the sale or transfer of DOE property are those associated with the closure of hazardous waste or radioactive mixed waste (RMW) disposal units (i.e., units at which wastes remain in place after closure). These regulations were promulgated to address closure and post-closure requirements that include ensuring that the locations of former disposal units are known to new property owners [40 CFR 264 and 265 Subpart (j].

After closure of each disposal unit, owners or operators must submit a survey plat to the local zoning authority (or to the authority with jurisdiction over local or surrounding land use) and to EPA or the authorized State. The plat must identify the location and dimensions of each disposal unit with respect to permanent benchmarks and must be prepared by a professional land surveyor [40 CFR 264.116 and 265.116]. Within 60 days of the certification of closure of a disposal unit, a record of the type, location, and quantity of hazardous waste or hazardous components of RMW must be submitted to the local zoning authority and EPA or the authorized State [40 CFR 264.119(a) and 265.119(a)]. In addition, the owner or operator must record a notation on the deed to the facility property that will, in perpetuity, notify any potential purchaser of the property that:

the land has been used to manage hazardous waste or RMW,

$\square$ the use of the land is restricted under 40 CFR 264 and 265 Subpart $\mathrm{G}$ regulations, and

the survey plat and record of the type, location, and quantity of waste have been filed with the local zoning authority and EPA or the authorized State.

Within 60 days of certification of closure of the first disposal unit and within 60 days of certification of closure of the last disposal unit, a signed certification that the notation was recorded must be submitted to EPA or the authorized State, and a copy of the document in which the notation was placed must be included in the submission [40 CFR 264.119 (b) and 265.119(b)].

Which CERCLA regulations are pertinent to the sale or transfer of DOE property?

Regulations promulgated by EPA under Sections $120(\mathrm{~h})(1)$ and (2) of CERCLA require that departments, agencies, and instrumentalities of the United States provide notice of the storage, release, or disposal of hazardous substances in contracts for the sale or transfer of real property owned by the United States. These regulations, located in 40 CFR 373, are applicable to properties where:

J hazardous substances in quantities greater than or equal to $1,000 \mathrm{~kg}$, or the CERCLA reportable quantity $(R Q)$, whichever is greater, were stored for 1 year or more;

acutely hazardous substances in quantities greater than or equal to $1 \mathrm{~kg}$ were stored for 1 year or more;

I hazardous substances were released in quantities equal to or greater than their CERCLA RQ; or

$\sqsupset$ hazardous substances were disposed of [40 CFR 373.2].

To the extent that such information is available (based on a complete search of DOE files) the notice must include:

substance identifiers (the name of the hazardous substance, the Chemical Abstracts Service (CAS) registry number, hazardous waste number, etc.); and

the quantity of the hazardous substance that was stored, released, or disposed of on the property and the dates of storage, release, or disposal [40 CFR 373.3].

$$
\text { b }
$$

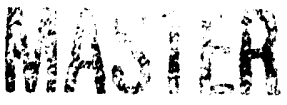

Printed on Recycled Paper 


\section{DISCLAIMER}

This report was prepared as an account of work sponsored by an agency of the United States Government. Neither the United States Government nor any agency thereof, nor any of their employees, makes any warranty, express or implied, or assumes any legal liability or responsibility for the accuracy, completeness, or usefulness of any information, apparatus, product, or process disclosed, or represents that its use would not infringe privately owned rights. Reference herein to any specific commercial product, process, or service by trade name, trademark, manufacturer, or otherwise does not necessarily constitute or imply its endorsement, recommendation, or favoring by the United States Government or any agency thereof. The views and opinions of authors expressed herein do not necessarily state or reflect those of the United States Government or any agency thereof. 
What additional requirements associated with the sale or transfer of property does Section 120(h)(3) of CERCLA Impose on DOE?

Section 120(h)(3) of CERCLA requires that the following information be placed in deeds for any transfer of United States property where hazardous substances were stored for more than 1 year, disposed of, or released (to the extent that such information is available, based on a complete search of DOE files):

A notice of the type and quantity of hazardous substances stored, disposed of, or released;

A notice of the time at which such storage, disposal, or release took place; and

A description of any remedial action taken.

Also required in the deed is a covenant warranting that:

all remedial action necessary to protect human health and the environment has been taken, and

a any additional remedial action found to be necessary shall be conducted by the United States.

\section{How did the passage of CERFA amend Section 120(h)(3) of CERCLA?}

The October 1992 passage of the CERFA (PL 102-426) amended Section 120(h)(3) of CERCLA to clarify the extent of remedial action necessary to protect human health and the environment on property where hazardous substances were stored, disposed of, or released. Remedial action necessary to protect human health and the environment is deemed to have been taken if the construction and installation of an approved remedial design has been completed and the remedy has been demonstrated to EPA to be operating properly and successfully. Long-term pumping and treating of ground water and continued operation and maintenance of remediation projects, therefore, does not preclude the sale or transfer of DOE property.

What additional requirements associated with the sale or transfer of property do Sections $120(h)(4)$ and (5) of CER SLA Impose on DOE?

Sections $120(\mathrm{~h})(4)$ and $120(\mathrm{~h})(5)$ of CERCLA, also added by CERFA, contain requirements pertinent to the sale, transfer, and lease of DOE property. Before properties can be sold or transferred, the heads of U.S. Government entities must determine whether the properties are uncontaminated [Section 120(h)(4)]. The following sources of information must be reviewed to make this determination:

Federal Government records,

Recorded chain of title documents,

Reasonably obtainable aerial photographs,

Visual inspection of the property and adjacent properties,

Reasonably obtainable records of releases on adjacent properties,

Interviews with current or former employees, and

a Sampling, if appropriate under the circumstances [Section $120(\mathrm{~h})(4)(\mathrm{A})]$.
The EPA Administrator must concur with the results of the determination for properties that are part of facilities on the CERCLA National Prionities List. For other properties, concurrence is required from the appropriate State official [Section 120(h)(4)(B)]. The determination, and EPA or State concurrence with the determination, must be accomplished at least 6 months before termination of operations on the property [Section $120(\mathrm{~h})(4)(\mathrm{C})(\mathrm{i})]$. In addition, the deed for the sale or transfer of uncontaminated property must contain:

a covenant warranting that any response action or corrective action found to be necessary after the date of sale or transfer shall be conducted by the United States [Section 120(h)(4)(D)(i)], and

a clause granting the United States access to the property in any case in which a response action or corrective action is found to be necessary on the property or on an adjoining property [Section 120(h)(4)(D)(ii)].

The U.S. Government entity with jurisdiction over property on which any hazardous substance, petroleum product, or petroleum product derivative was stored, disposed of, or released must notify the State in which the property is located before entering into a lease that would encumber the property beyond the date of the U.S. Government's termination of operations on the property [Section $120(h)(5)]$.

What is the effect of fulfilling RCRA and CERCLA requirements associated with the sale or transfer of DOE property?

The effect of fulfilling the RCRA and CERCLA requirements described above is to alter the post-transaction rights and remedies of DOE and buyers or holders of DOE properties. DOE's fulfillment of these requirements makes it more difficult for buyers or holders to assert legal claims against the Department because they were not informed of the former uses, restrictions on future uses, and liabilities associated with these properties.

Further, the remediation, corrective action, deed restrictions, and covenants required under Sections $120(\mathrm{~h})(3)$ and $120(\mathrm{~h})(4)$ of CERCLA provide protection against future environmental liability costs to buyers of DOE property. Congress passed CERFA in the hopes that this protection would serve to facilitate the sale, transfer, and redevelopment of Federal property.

Section 120(h)(4) of CERCLA allows EPA and States to review DOE decisions determining whether or not properties are contaminated. This section ensures that DOE decisions that determine which properties are suitable for sale or transfer are themselves subject to review.

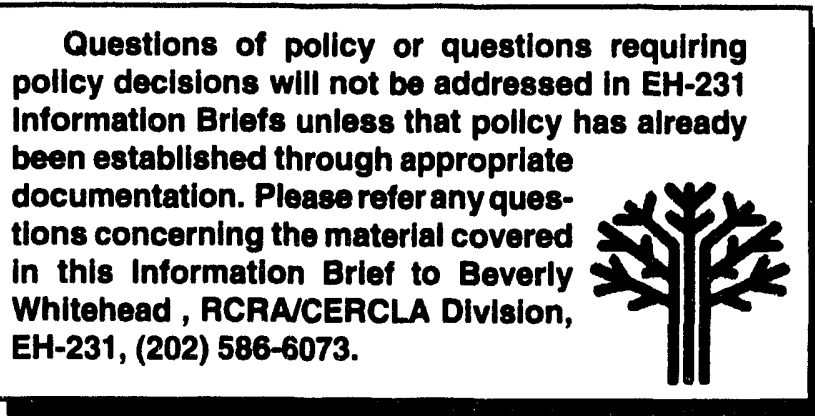



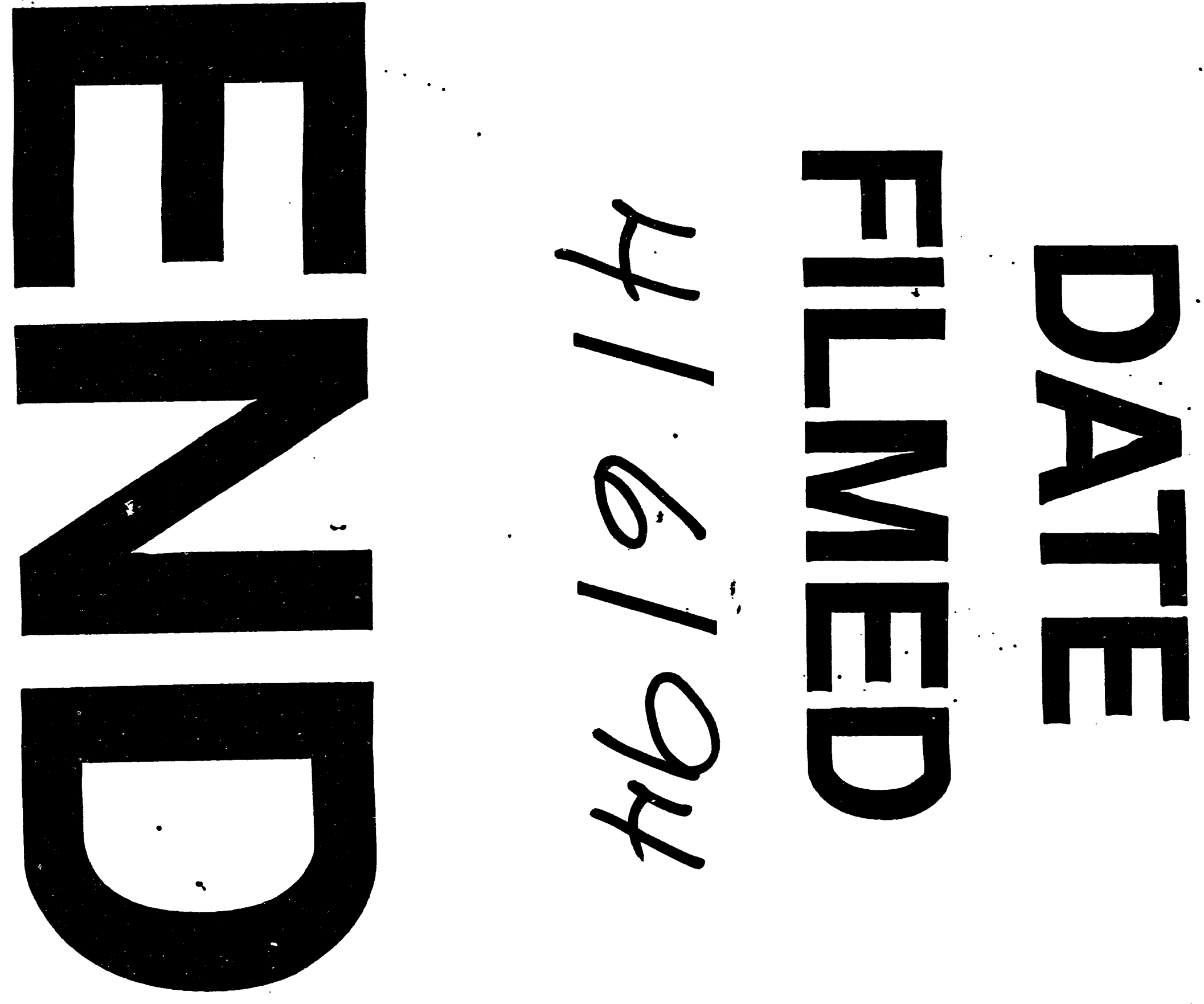


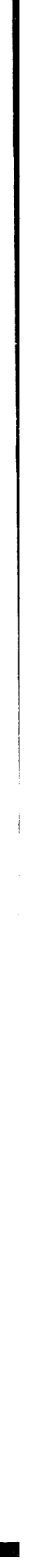

